\title{
Seed Germination and Initial Growth of Pepper Seedlings is Influenced by Environment Temperature and Priming Method
}

\author{
Glenda Sallaku \\ Agricultural University of Tirana, Tirana, Albania \\ Tel: +355689013982Ｅ-mail: gsallaku@ubt.edu.al
}

Gjok Vuksani

Agricultural University of Tirana, Tirana, Albania

Tel: +3556672041391Ｅ-mail: gjvuksani@ubt.edu.al

Astrit Balliu (Corresponding author)

Agricultural University of Tirana, Tirana, Albania

Tel: +355686022105_E-mail: aballiu@ubt.edu.al

Received: Sep. 23, $2020 \quad$ Accepted: Oct. 11, $2020 \quad$ Published: Oct. 15, 2020

doi:10.5296/jas.v8i4.17831～URL: https://doi.org/10.5296/jas.v8i4.17831

\begin{abstract}
The effects of different environment temperatures, priming treatments and priming durations on germination parameters and early growth of pepper seedlings were investigated. Seeds were hydro primed in distilled water, or osmo primed in two different water potentials $(-0.15$ and $-0.5 \mathrm{MPa}$ ) of polyethylene glycol (PEG) 8000. Both, hydro primed and osmo primed seeds were subject of two different imbibitions periods, 48 and $72 \mathrm{hrs}$. In addition to primed seeds, an equal sample of non primed seeds was included in the experiment as a control variant. Following priming, the seeds were subjected to germination tests at two different environment temperatures, respectively $18{ }^{\circ} \mathrm{C}$ and $24{ }^{\circ} \mathrm{C}$. In general, there was no significant effect of hydro priming on germination parameters or early growth of pepper seedlings. On the contrary, significantly higher germination percentage and germination speed and significantly shorter mean germination time than the non primed seeds were obtained due to
\end{abstract}


seed osmo priming by PEG. Similarly, an enhanced seedling growth, especially under suboptimum temperature conditions was evidenced in PEG primed seedlings. Apart from germination speed, the increase of PEG concentration from -0.15 to $-0.5 \mathrm{MPa}$ had no effect to germination parameters of pepper seeds. The extent of the imbibitions period over $48 \mathrm{hrs}$ did also have no benefits on germination parameters.

Keywords: Final germination percentage, germination speed, mean daily germination, mean germination time, germination uniformity, dry matter

\section{Introduction}

Among various types of biotic and abiotic stresses, salinity, drought, and temperature cause low growth and development, by inducing reactive oxygen species (ROS) production in a plant cell. The cold stress can causes mayhem in plants by inducing chlorosis, necrosis, membrane damage, changes in cytoplasm viscosity, changes in enzyme activities and ultimately death (Sharma and Laxmi, 2016), but the most principal effect of low temperature is to delay the period of more rapid growth (Robertson, 1961).

While crop yield and resource use efficiency depend on successful plant establishment in the field (Finch-Savage and Bassel, 2016), it has been widely reported that chilling stress severely hampers the uniformity and rate of germination, seedling vigor, and delays the plant development stages, leading to severe yield losses (Ghassemi-Golezani et al., 2011; Hussain et al., 2016b). Therefore, improving vigor to enhance the critical and yield-defining stage of crop establishment remains a primary objective of the agricultural industry and the seed/breeding companies that support it (Finch-Savage and Bassel, 2016).

Seed priming, i.e., the physiological process of controlled seed hydration, is considered a useful technique to improve germination of many crop species, particularly under adverse conditions such as low temperature (Elkoca et al., 2007). In addition it enhances seed germination uniformity, and seedling growth and development in both normal and stress conditions (Waqas et al., 2019), alleviate the toxic effects of heavy metals stress (Salah et al., 2015), and improves salt (Balliu et al., 2016) and chilling tolerance (Salah et al., 2015).

Several methods of seed priming have been developed in order to invigorate seeds and alleviate the environmental stresses. Hydro priming is the simplest method of seed priming. Basically hydro priming means soaking seeds soaking in pure water and then dries back to original moisture content prior to sowing. The main disadvantage of hydro priming is uncontrolled water uptake by seeds. This is a consequence of free water availability to seeds during hydro priming, so that the rate of water uptake depends only on seed tissue affinity to water (Lutts $e t$ $a l ., 2016)$. In addition, osmo priming is a widely used commercial technique in which seeds are hydrated to a controlled level to allow pre germination metabolic activities. During this process an excess entry of water into seed might result in reactive oxygen species (ROS) accumulation and oxidative damage of cellular components such as proteins, lipid membranes, and nucleic acids. By delaying water entry to seed osmo priming reduces the ROS accumulation and thus protects the cell from oxidative injury (Waqas et al., 2019).

Although, the physiological reasons behind the improved germination and seedling 
establishment after seed priming are rather unclear (Zhang et al., 2015), several hypothesis such the drop in $\mathrm{H}_{2} \mathrm{O}_{2}$ accumulation, restoration of catalase activity, increased protein content in various plant tissues via improved performance of protein synthesis system and increased production of specific enzymes that plays an important role in repairing plant tissue proteins, and enhanced activity of protease and amylase that hydrolyze protein and starch into simple forms to make them available for the embryo are provided (Waqas et al., 2019).

Commonly, the effects of priming are linked with the enhanced capabilities of plant seeds to germinate. Therefore, in this experiment the effects of hydro priming and osmo priming were studied in regard to most important germination parameters and the growth of pepper seedlings, soon after the germination process was completed, under optimum and sub optimum environment temperature conditions.

\section{Method}

The experiment was conducted during the spring of 2020 under growth controlled conditions in the experimental premises of Agricultural University of Tirana, Albania. Graded seeds of a commercial pepper variety (Capsicum annum L. cv. Belorozec $\mathrm{F}_{1}$; SEMO a.s., Smirzice, Czech Republic) were used in the experiment. Several variants were been tested; control (ctr), hydropriming (hp) by distilled water, and osmopriming by two different concentration of polyethylene (PEG 8000) osmotic solution, respectively -0.15 MPa (op1) and -0.5 MPa (op2) (Villela et al., 1991). Seeds of 'hp' and 'op' variants were each split in two equal parts, 100 seeds each half, and fully immersed in respective aerated solution for 48 hours (half) and 72 hrs (next half), in dark conditions, at a germination room $\left(24{ }^{\circ} \mathrm{C}, 80 \% \mathrm{RH}\right)$. The ratio of seed weight to solution volume (w/v) was 1:5. After respective imbibition period, primed seeds were washed with distilled water for 2 min, surface-dried using blotting paper, and transferred again for next 48 hours at the same conditions $\left(24^{\circ} \mathrm{C}, 80 \% \mathrm{RH}\right)$. The control variant was also kept at the same conditions for the last 48 hours. Following that procedure, all seeds were sown in polysterol trays, filled with peat ( $\sim 100 \mathrm{~cm} 3$ per each module) and transferred in two different growth chambers with different temperature regimes, respectively $18^{\circ} \mathrm{C}$ and $24^{\circ} \mathrm{C}$. Equal $\mathrm{RH}(80 \%)$ and lightening conductions (12 hrs, PPFD $180 \mu \mathrm{mol} \mathrm{m}-2 \mathrm{~s}-1)$ were applied. Immediately after sowing the substrate was brought to full water capacity thorough the irrigation with tap water. After that, uniform irrigations were applied, as required to maintain the substrate at optimum humidity.

Each treatment was replicated three times; twenty seeds were used to each replication and the germinated seeds were counted from day 1 to day 18. Following that, the following germination parameters were determined according to (Ranal and De Santana, 2006) and (Damalas et al., 2019):

1. Final germination $(\mathrm{FG})(\%)$,

$$
F G=\frac{N_{g}}{N_{t}} 100
$$

where; $N_{g}$ - is the number of germinated seeds and $N_{t}-$ is the total number of seeds.

2. Germination speed (GS) ( 


$$
G S=\frac{\sum n t}{\sum n}
$$

where; $\mathrm{nt}$ - number of normal germinated seeds at time ' $\mathrm{t}$ '.

3. Mean germination time (MGT) (day),

$$
M G T=\frac{\sum\left(n_{1} T_{1}+n_{2} T_{2}+\cdots+n_{k} T_{k}\right)}{\sum\left(n_{1}+n_{2}+\cdots+n_{k}\right)}
$$

where; $\mathrm{n}$ - number of newly germinated seeds and $\mathrm{T}$ - time from the beginning of the experiment.

4. Mean daily germination (MDG) $\left(\right.$ seeds day $\left.{ }^{-1}\right)$,

$$
M D G=\frac{F G}{T}
$$

where; FG - final germination and T number of days after the start of the test.

5. Synchronization index (SI) (unitless),

$$
S I=-\sum f_{\mathrm{i}} \log _{2} f_{\mathrm{i}}
$$

where; fi - relative frequency of germination, $f i={ }^{n_{i}} / \sum_{\sum_{i}^{k}} n_{i} ; n i-$ number of germinated seeds

on te day ' $\mathrm{i}$ ', and k- the last day of testing. Low values of synchronization index (SI) indicate more synchronized germination.

In addition to above, at DAS (day after sowing) 20, ten plant of each variant were randomly selected and harvested. The root system was gently washed free of adhering peat particles and plants were dissected in roots and shoots. The plant organs were subsequently dried $\left(65^{\circ} \mathrm{C}, 48\right.$ h) and weighted separately to an accuracy of $0.001 \mathrm{~g}$ (TP 303; Denver Instruments GmbH, Göttingen, Germany). Following that, dry matter of roots $\left(\mathrm{DM}_{\mathrm{root}}\right)$ and dry matter of shoots $\left(\mathrm{DM}_{\text {shoot}}\right)$ were individually recorded for each plant.

A three replicate split plot design with temperature $(\mathrm{T})$ as the main plots and priming methods (Pm) as subplots was used. Residuals of all variables were tested for homogeneity of variances and normality using the tests after Brown-Forsythe and Shapiro-Wilk, respectively. Differences in DM, FG, GS, MDG, MDG and SI were tested by two way ANOVA, using the PC program SigmaPlot 13 (Systat Software Inc., San Jose, CA, USA). Each significant ANOVA result $(\mathrm{p}<0.05)$ was followed by a Tukey-Kramer tests at $\mathrm{p}<0.05$ as post-hoc test. Values given throughout the text are means \pm SE. 


\section{MInstitute"}

\section{Results}

The influence of temperature on seed germination parameters was strong and significant. As a rule, by increasing the environment temperature from $18{ }^{0} \mathrm{C}$ to $24{ }^{0} \mathrm{C}$ the germination process becomes faster. Indeed, by increasing the temperature the germination speed (GS) was almost

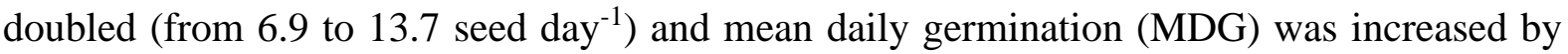
$44 \%$ (from 4.3 to 6.1 seed day $^{-1}$ ). On the contrary, mean germination time (MGT) was decreased by $68 \%$ (from 17.8 to 12.2 days). Overall, due to increased environment temperature the final germination (FG) was increased by $9 \%$ (from 89.3 to $97.6 \%$ ), but no significant effect of temperature was found regarding SI (data not shown).

The effect of temperature remains strong after seed germination was completed. Therefore, significant differences due to different environment temperatures were found regarding dry matter of roots $\left(\mathrm{DM}_{\text {roots }}\right)$, shoots $\left(\mathrm{DM}_{\text {shoot }}\right)$, dry matter of entire plant $\left(\mathrm{DM}_{\text {plant }}\right)$ and the ratio between $\mathrm{DM}_{\text {root }}$ and $\mathrm{DM}_{\text {shoot }}$. By DAS 20, due to the raise of temperature $\mathrm{DM}_{\text {roots }}$ was reduced by $67 \%$ (from 0.0018 to 0.0012 gr plant $^{-1}$ ), but on the contrary a larger shoot biomass was promoted. The above ground biomass of pepper seedlings was doubled (from 0.0056 to $0.0115 \mathrm{gr} \mathrm{plant}^{-1}$ ) and the entire $\mathrm{DM}_{\text {plant }}$ was increased by $71 \%$ (from 0.0075 to $0.0128 \mathrm{gr}$ plant $\left.^{-1}\right)$. The most significant result of different responses roots and shoots had to the change in environment temperature was the highly significant change of the ratio between $\mathrm{DM}_{\text {root }}$ and $\mathrm{DM}_{\text {shoot }}$ decreased by $36 \%$.
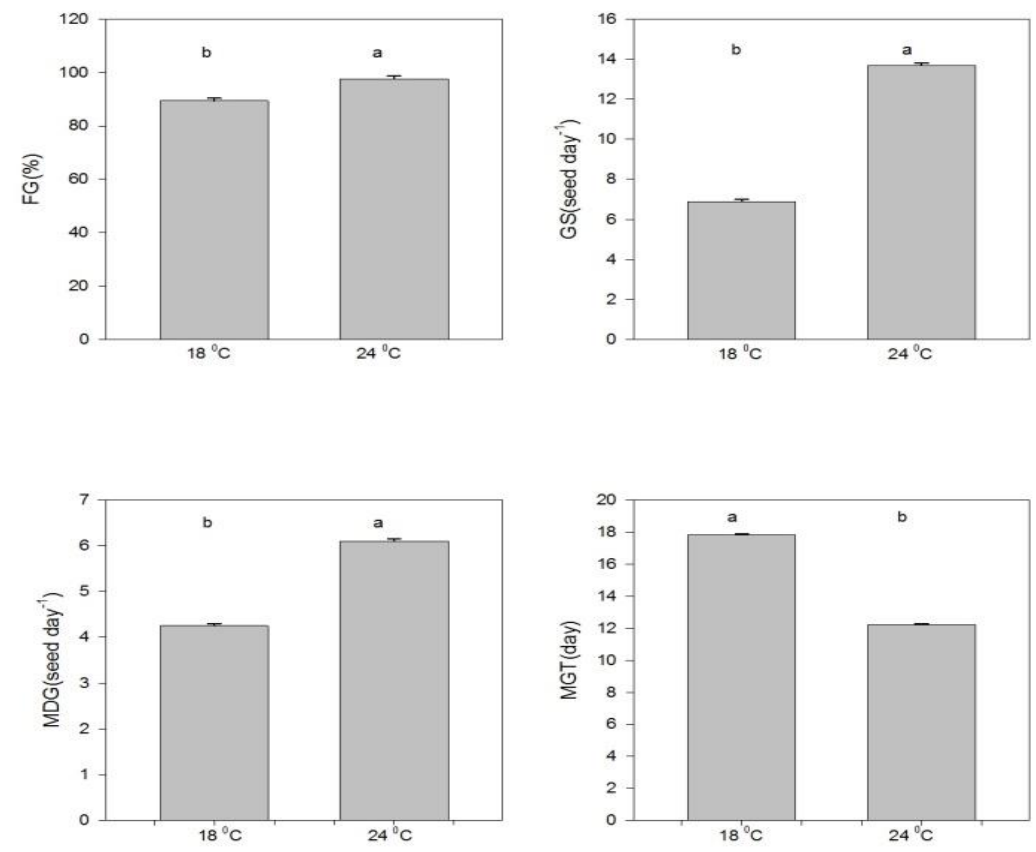

Figure 1. Final germination (FG), germination speed (GS), mean daily germination (MDG) and mean germination time (MGT) under two different levels of environment temperature (18 and $24^{\circ} \mathrm{C}$ ). Mean values over non primed (ctr) and primed (hp 48, hp 72, op1 48, op1 72, op2 48, op2 72) variants. Different letters indicate significant differences within following parameters (Holm-Sidak method, $\mathrm{p}<0.05$; mean \pm SE) 

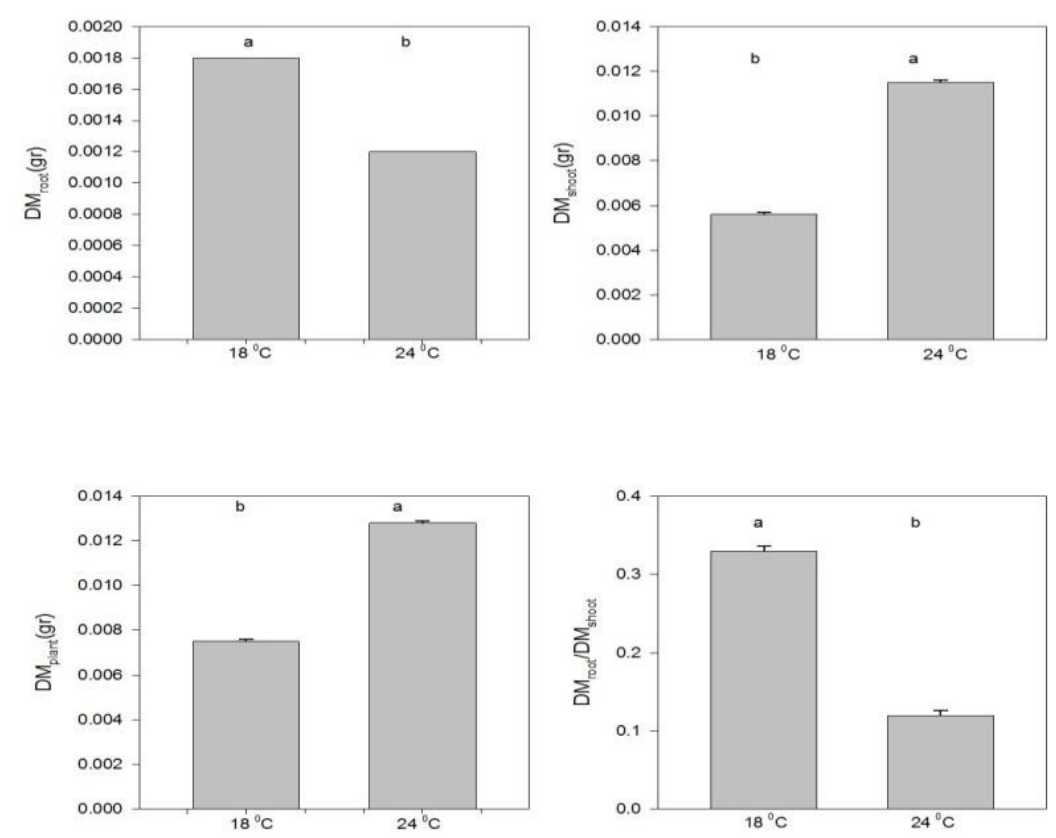

Figure 2. Dry matter of roots $\left(\mathrm{DM}_{\mathrm{root}}\right)$, dry matter of shoots $\left(\mathrm{DM}_{\text {shoot }}\right)$, dry matter of plant (DM $\mathrm{Dlant}_{\text {pl }}$, and $\mathrm{DM}_{\text {root: }}: \mathrm{DM}_{\text {Shoot }}$ ratio under two different levels of environment temperature (18 and $24{ }^{\circ} \mathrm{C}$ ). Mean values over non primed (ctr) and primed (hp 48, hp 72, op1 48, op1 72, op2 48, op2 72) variants. Different letters indicate significant differences within following parameters (Holm-Sidak method, $\mathrm{p}<0.05$; mean \pm SE)

The seed germination parameters were as well strongly influenced by different priming methods (Figure 3). Compared to priming, the control variant (ctr) had the lowest values of FG $(88.3 \%)$, GS $\left(9.1\right.$ seeds day $\left.{ }^{-1}\right)$ and MDG (4.9 seeds day $\left.{ }^{-1}\right)$. The entire germination process to the control variant was the longest among all variants, clearly proved by the highest MGT value (15.3 day). The control variant had as well the smallest value of SI (data not shown).

The effect of priming methods on seed germination parameters were significantly distinguished from each other. Indeed, although slightly better than control, both hydro priming variants (48 hrs and $72 \mathrm{hrs}$ ) shows no significant difference versus control (Figure 3). On the contrary, osmo priming had significantly improved FG and MDG vs. control by nearly $10 \%$, and SG even more (14 to 26\%). No significant differences exist among osmo priming variants themselves regarding FG and MDG, whereas "op 2" variants showed significantly higher SG values than "op1". No effect of length of imbibition period with PEG solution was found regarding every each of germination parameters. Surprisingly to us, the control variant had a significantly smaller SI value than all, either hydro primed or osmo primed variants (data not shown). 

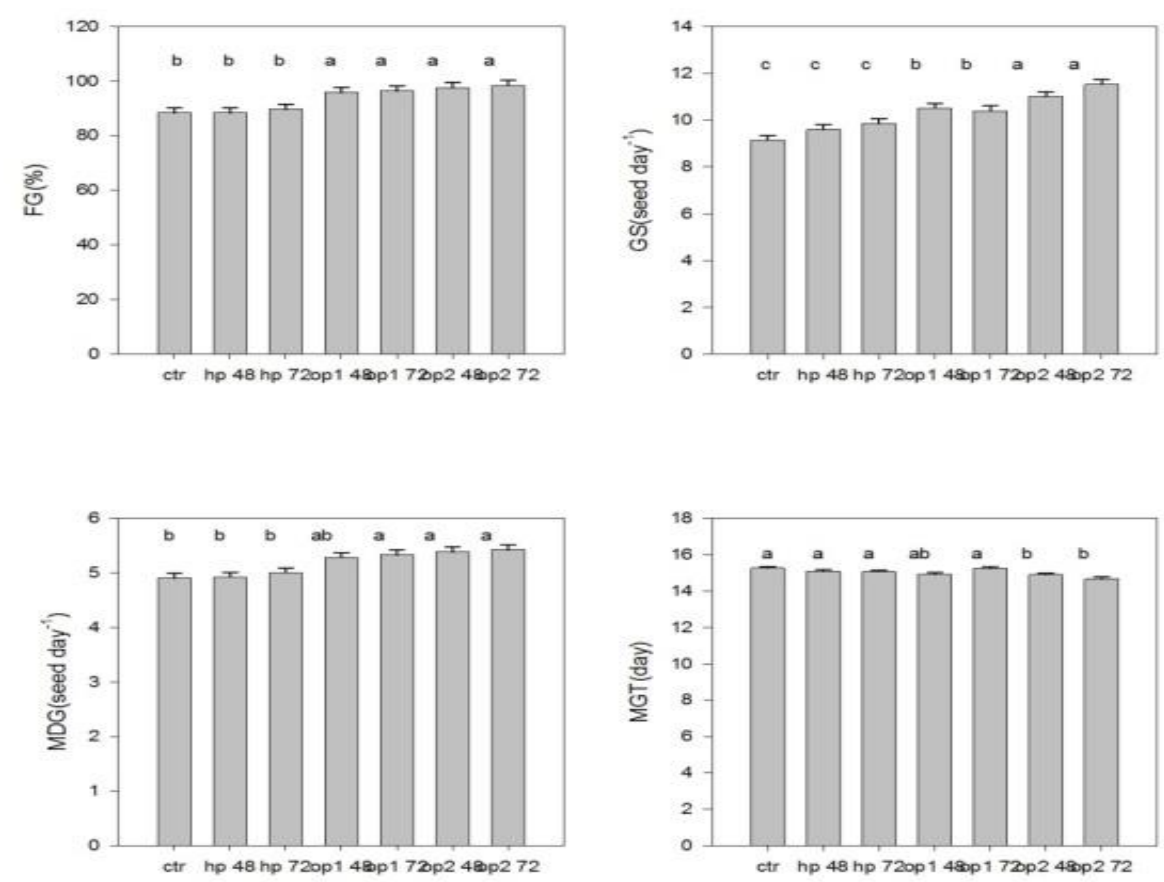

Figure 3. Final germination (FG), germination speed (GS), mean daily germination (MDG) and mean germination time (MGT) of non primed (ctr) and primed (hp 48, hp 72, op1 48, op1

72, op2 48, op2 72) variants. Mean values over two different levels of environment temperature $\left(18\right.$ and $\left.24{ }^{\circ} \mathrm{C}\right)$. Different letters indicate significant differences within following parameters (Holm-Sidak method, $\mathrm{p}<0.05$; mean \pm SE)
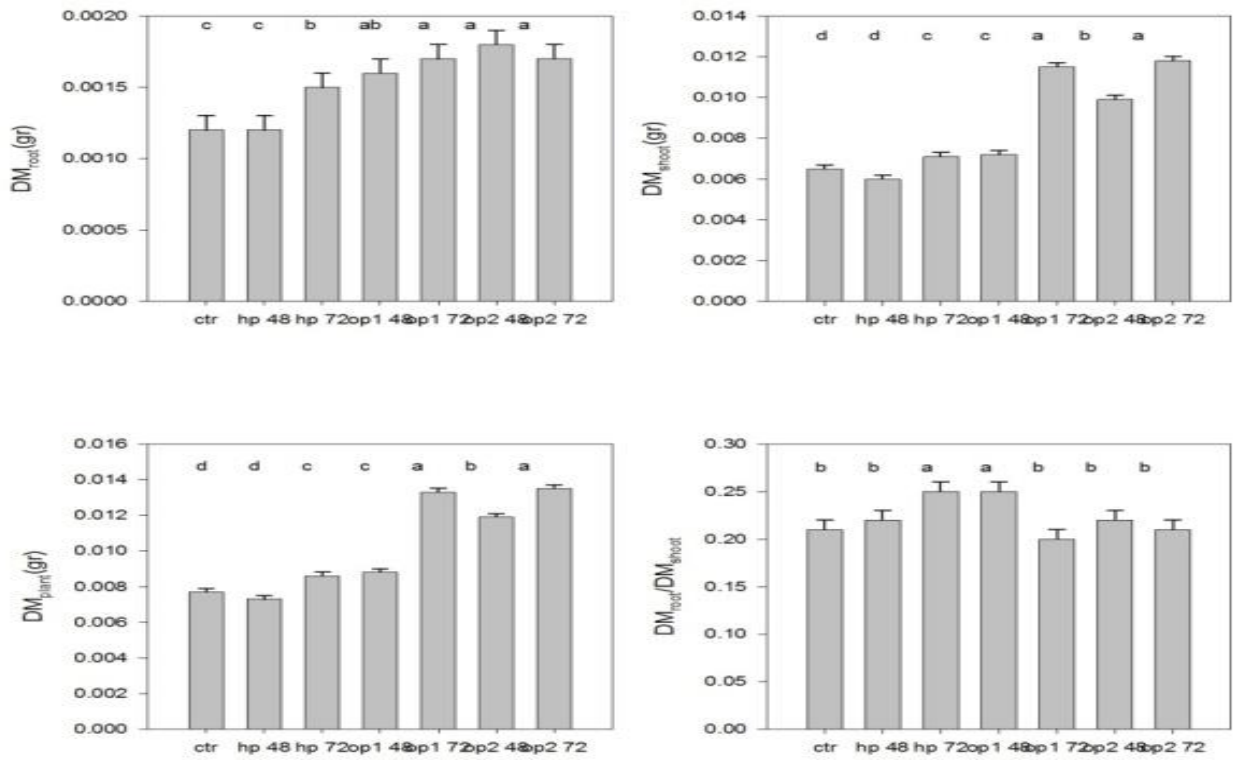

Figure 4. Dry matter of roots $\left(\mathrm{DM}_{\mathrm{root}}\right)$, dry matter of shoots $\left(\mathrm{DM}_{\text {shoot }}\right)$, dry matter of plant $\left(\mathrm{DM}_{\text {plant }}\right)$, and $\mathrm{DM}_{\text {root: }}: \mathrm{DM}_{\text {Shoot }}$ ratio of non primed (ctr) and primed (hp 48, hp 72, op1 48, op1

72 , op2 48, op2 72) variants. Mean values over two different levels of environment temperature $\left(18\right.$ and $\left.24{ }^{\circ} \mathrm{C}\right)$. Different letters indicate significant differences within following parameters (Holm-Sidak method, $\mathrm{p}<0.05$; mean \pm SE). 


\section{Mll Macrothink}

Journal of Agricultural Studies

ISSN 2166-0379

2020, Vol. 8, No. 4

Clearly, primed seeds developed a larger root system. The dry matter of roots in primed seeds was $25-50 \%$ higher than in control plants. The only exception was "hp48" which shows no difference compared with control. A similar response was found regarding $\mathrm{DM}_{\text {shoot, }}$ which was increased up to $20 \%$ in "hp" variant and up to $80 \%$ in "op" variants. Interestingly, the extent of seed imbibition period with either with pure water or PEG solutions, from $48 \mathrm{hrs}$ to $72 \mathrm{hrs}$ was followed by a significant increase in $\mathrm{DM}_{\text {shoot. }}$ Obviously, $\mathrm{DM}_{\text {plant }}$ followed the same trend of $\mathrm{DM}_{\text {shoot, }}$ whereas the effect of priming method to $\mathrm{DM}_{\text {root: }} \mathrm{DM}_{\text {shoot }}$ ratio was not clear. It was significantly higher than control only in "hp72" and 'op1 48" variants. No differences were found among other variants.

Table 1. Final germination (FG), germination speed (GS), mean daily germination (MDG), mean germination time (MGT) and synchronization index (SI) of non primed (ctr) and primed (hp 48, hp 72, op1 48, op1 72, op2 48, op2 72) under two different levels of environment temperature $\left(18\right.$ and $\left.24{ }^{\circ} \mathrm{C}\right)$. Different letters indicate significant differences within following parameters (Holm-Sidak method, $\mathrm{p}<0.05$; mean $\pm \mathrm{SE}$ )

\begin{tabular}{|c|c|c|c|c|c|c|}
\hline $\mathrm{T}$ & Variant & FG (\%) & $\begin{array}{r}\text { GS (seed } \\
\text { day }^{-1} \text { ) } \\
\end{array}$ & $\begin{array}{r}\text { MDG (seed } \\
\left.\text { day }^{-1}\right) \\
\end{array}$ & MGT (day) & E (unitless) \\
\hline \multirow{7}{*}{$\begin{array}{l}\cup \\
\infty \\
\infty\end{array}$} & ctr & $83.33 \pm 2.69 b$ & $5.29 \pm 0.29 c$ & $3.96 \pm 0.13 c$ & $18.5 \pm 0.13 \mathrm{a}$ & $0.36 \pm 0.02 b$ \\
\hline & hp 48 & $80.00 \pm 2.69 b$ & $5.81 \pm 0.29 \mathrm{c}$ & $3.81 \pm 0.13 \mathrm{c}$ & $18.1 \pm 0.13 \mathrm{a}$ & $0.68 \pm 0.02 \mathrm{a}$ \\
\hline & hp 72 & $82.77 \pm 2.69 b$ & $5.48 \pm 0.29 \mathrm{c}$ & $3.94 \pm 0.13 c$ & $18.4 \pm 0.13 \mathrm{a}$ & $0.70 \pm 0.02 \mathrm{a}$ \\
\hline & op1 48 & $95.00 \pm 2.69 \mathrm{a}$ & $7.96 \pm 0.29 \mathrm{a}$ & $4.52 \pm 0.13 b$ & $17.3 \pm 0.13 b$ & $0.69 \pm 0.02 \mathrm{a}$ \\
\hline & op1 72 & $92.77 \pm 2.69 a$ & $7.33 \pm 0.29 b$ & $4.41 \pm 0.13 b$ & $17.6 \pm 0.13 b$ & $0.67 \pm 0.02 \mathrm{a}$ \\
\hline & op2 48 & $95.00 \pm 2.69 \mathrm{a}$ & $7.63 \pm 0.29 \mathrm{a}$ & $4.52 \pm 0.13 \mathrm{a}$ & $17.7 \pm 0.13 b$ & $0.71 \pm 0.02 \mathrm{a}$ \\
\hline & op2 72 & $96.66 \pm 2.69 \mathrm{a}$ & $8.64 \pm 0.29 \mathrm{a}$ & $4.60 \pm 0.13 \mathrm{a}$ & $17.2 \pm 0.13 b$ & $0.77 \pm 0.02 \mathrm{a}$ \\
\hline \multirow{7}{*}{ 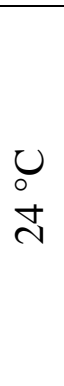 } & $\mathrm{ctr}$ & $93.3 \pm 2.69 \mathrm{~b}$ & $12.99 \pm 0.29 b$ & $5.83 \pm 0.13 b$ & $12.0 \pm 0.13 b$ & $0.54 \pm 0.02 b$ \\
\hline & hp 48 & $96.6 \pm 2.69 \mathrm{ab}$ & $13.37 \pm 0.29 b$ & $6.04 \pm 0.13 \mathrm{ab}$ & $12.1 \pm 0.13 b$ & $0.65 \pm 0.02 \mathrm{a}$ \\
\hline & hp 72 & $96.6 \pm 2.69 \mathrm{ab}$ & $14.21 \pm 0.29 b$ & $6.04 \pm 0.13 \mathrm{ab}$ & $11.7 \pm 0.13 b$ & $0.62 \pm 0.02 \mathrm{a}$ \\
\hline & op1 48 & $96.6 \pm 2.69 \mathrm{ab}$ & $13.05 \pm 0.29 b$ & $6.04 \pm 0.13 \mathrm{ab}$ & $12.6 \pm 0.13 \mathrm{a}$ & $0.67 \pm 0.02 \mathrm{a}$ \\
\hline & op1 72 & $100.0 \pm 2.69 \mathrm{a}$ & $13.44 \pm 0.29 b$ & $6.25 \pm 0.13 a$ & $12.8 \pm 0.13 \mathrm{a}$ & $0.65 \pm 0.02 \mathrm{a}$ \\
\hline & op2 48 & $100.0 \pm 2.69 a$ & $14.37 \pm 0.29 \mathrm{a}$ & $6.25 \pm 0.13 a$ & $12.1 \pm 0.13 b$ & $0.61 \pm 0.02 \mathrm{a}$ \\
\hline & op2 72 & $100.0 \pm 2.69 \mathrm{a}$ & $14.40 \pm 0.29 \mathrm{a}$ & $6.25 \pm 0.13 a$ & $12.1 \pm 0.13 b$ & $0.67 \pm 0.02 \mathrm{a}$ \\
\hline \multicolumn{2}{|c|}{ Variant $(\mathrm{V})$} & $<0.001$ & $<0.001$ & $<0.001$ & 0.003 & $<0.001$ \\
\hline \multicolumn{2}{|c|}{ Temperat. (T) } & $<0.001$ & $<0.001$ & $<0.001$ & $<0.001$ & 0.082 \\
\hline $\begin{array}{l}\mathrm{V} \\
\text { int }\end{array}$ & $\mathrm{x}$ & 0.082 & $<0.001$ & 0.157 & $<0.001$ & $<0.001$ \\
\hline
\end{tabular}

Significant variant $x$ temperature interactions were found regarding GS, MGT and SI (Table 1), but not regarding FG and MDG. Clearly the trends discussed above regarding all germination parameters were found to be true, each tested environment temperatures. The control variant showed the lowest values of FG, GS, and MDG at both, $18{ }^{0} \mathrm{C}$ and $24{ }^{0} \mathrm{C}$ temperatures. Hydro priming did not brought any improvement regarding these parameters at $18{ }^{0} \mathrm{C}$ temperature, but slight improvements vs. control were noticed at $24{ }^{0} \mathrm{C}$. Contrary to hydro priming, osmo priming had in general significantly improved FG, GS and MDG vs. control. The advantages over control were significant despite of temperature range. Overall, 
there was no effect of increased concentrations of PEG solutions. The only advantage of a higher PEG concentration (-0.5 MPa) was found regarding GS at both temperature regimes and MDG (only at $18{ }^{\circ} \mathrm{C}$ temperature). Osmo priming did also significantly reduced MGT vs. control variants, but only in $18{ }^{\circ} \mathrm{C}$ temperature regime. No effect was found under $24{ }^{0} \mathrm{C}$ temperature regime (Table 1). Surprisingly, priming has negatively affected germination synchronization (SI) and that's was true at both temperature regimes (Table 1). However, by increasing temperature, SI values in the control variant were increased up (from 0.36 to 0.54 ), whereas remained constant in all primed variants.

Table 2. Dry matter of roots $\left(\mathrm{DM}_{\text {root }}\right)$, dry matter of shoots $\left(\mathrm{DM}_{\text {shoot }}\right)$, dry matter of plant $\left(\mathrm{DM}_{\text {plant }}\right.$ ), and $\mathrm{DM}_{\text {root }}: \mathrm{DM}_{\text {Shoot }}$ ratio of non primed (ctr) and primed (hp 48, hp 72, op1 48, op1 72, op2 48, op2 72) under two different levels of environment temperature (18 and $24{ }^{\circ} \mathrm{C}$ ). Different letters indicate significant differences within following parameters (Holm-Sidak method, $\mathrm{p}<0.05 ;$ mean \pm SE)

\begin{tabular}{|c|c|c|c|c|c|}
\hline $\mathrm{T}$ & Variant & $\mathrm{DM}_{\text {root }}$ & $\mathrm{DM}_{\text {shoot }}$ & $\mathrm{DM}_{\text {plant }}$ & $\mathrm{DM}_{\text {root: }} \mathrm{DM}_{\text {shoot }}$ \\
\hline \multirow{7}{*}{$\begin{array}{l}0 \\
0 \\
\infty\end{array}$} & $\mathrm{ctr}$ & $0.0015 \pm 0.0001 b$ & $0.0050 \pm 0.0003 b$ & $0.0066 \pm 0.0004 \mathrm{c}$ & $0.31 \pm 0.01$ \\
\hline & $\mathrm{hp} 48$ & $0.0016 \pm 0.0001 b$ & $0.0051 \pm 0.0003 b$ & $0.0067 \pm 0.0004 c$ & $0.31 \pm 0.01$ \\
\hline & hp 72 & $0.0016 \pm 0.0001 b$ & $0.0044 \pm 0.0003 c$ & $0.0060 \pm 0.0004 \mathrm{c}$ & $0.36 \pm 0.01$ \\
\hline & op1 48 & $0.0019 \pm 0.0001 \mathrm{a}$ & $0.0054 \pm 0.0003 b$ & $0.0074 \pm 0.0004 b$ & $0.35 \pm 0.01$ \\
\hline & op1 72 & $0.0019 \pm 0.0001 \mathrm{a}$ & $0.0066 \pm 0.0003 \mathrm{a}$ & $0.0085 \pm 0.0004 a$ & $0.31 \pm 0.01$ \\
\hline & op2 48 & $0.0021 \pm 0.0001 \mathrm{a}$ & $0.0068 \pm 0.0003 a$ & $0.0089 \pm 0.0004 a$ & $0.32 \pm 0.01$ \\
\hline & op2 72 & $0.0020 \pm 0.0001 \mathrm{a}$ & $0.0062 \pm 0.0003 \mathrm{a}$ & $0.0083 \pm 0.0004 a$ & $0.33 \pm 0.01$ \\
\hline \multirow{7}{*}{ 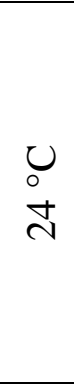 } & ctr & $0.0008 \pm 0.0001 b$ & $0.0079 \pm 0.0003 d$ & $0.0088 \pm 0.0004 d$ & $0.11 \pm 0.01$ \\
\hline & hp 48 & $0.0009 \pm 0.0001 b$ & $0.0069 \pm 0.0003 d$ & $0.0079 \pm 0.0004 d$ & $0.13 \pm 0.01$ \\
\hline & hp 72 & $0.0014 \pm 0.0001 \mathrm{a}$ & $0.0098 \pm 0.0003 c$ & $0.0113 \pm 0.0004 \mathrm{c}$ & $0.14 \pm 0.01$ \\
\hline & op1 48 & $0.0013 \pm 0.0001 \mathrm{a}$ & $0.0090 \pm 0.0003 c$ & $0.0104 \pm 0.0004 \mathrm{c}$ & $0.14 \pm 0.01$ \\
\hline & op1 72 & $0.0015 \pm 0.0001 \mathrm{a}$ & $0.0164 \pm 0.0003 a$ & $0.0179 \pm 0.0004 a$ & $0.09 \pm 0.01$ \\
\hline & op2 48 & $0.0015 \pm 0.0001 \mathrm{a}$ & $0.0132 \pm 0.0003 b$ & $0.0148 \pm 0.0004 b$ & $0.12 \pm 0.01$ \\
\hline & op2 72 & $0.0013 \pm 0.0001 \mathrm{a}$ & $0.0173 \pm 0.0003 a$ & $0.0187 \pm 0.0004 a$ & $0.08 \pm 0.01$ \\
\hline \multicolumn{2}{|c|}{ Variant $(\mathrm{V})$} & $<0.001$ & $<0.001$ & $<0.001$ & 0.006 \\
\hline \multicolumn{2}{|c|}{ Temperat. (T) } & $<0.001$ & $<0.001$ & $<0.001$ & $<0.001$ \\
\hline \multicolumn{2}{|c|}{ V x T interact. } & 0.624 & $<0.001$ & $<0.001$ & 0.416 \\
\hline
\end{tabular}

Significant variant $\mathrm{x}$ temperature effects were also found regarding $\mathrm{DM}_{\text {shoot }}$ and $\mathrm{DM}_{\text {plant }}$, but not regarding $\mathrm{DM}_{\text {root }}$ and nor the ratio between $\mathrm{DM}_{\text {root }}$ and $\mathrm{DM}_{\text {shoot }}$ (Table 2). It was obvious that the raise of temperature have boosted the growth of the above ground biomass, especially at osmo primed variants. It was also clear that this aboveground growth promotion effect was significantly influenced by the length of priming period; $72 \mathrm{hrs}$ treatments in hydro primed and osmo primed treatments recorded significantly higher $\mathrm{DM}_{\text {shoot }}$ values than $48 \mathrm{hrs}$ respective treatments (Table 2). The same was true regarding $\mathrm{DM}_{\text {plant. The raise of }}$ temperature significantly reduced $\mathrm{DM}_{\text {root }}: \mathrm{DM}_{\text {shoot }}$ ratio, but no effect of any of priming methods was found regarding it (Table 2). 


\section{Discussion}

Priming is defined as a physiological process by which a plant prepares to respond to imminent abiotic stress more quickly or aggressively (Jisha et al., 2013). Due to that, seedlings emerging from primed seeds showed early and uniform germination (Damalas et al., 2019; Faijunnahar et al., 2017; Hamidi and Pirasteh-anosheh, 2013), especially under adverse germination conditions. The beneficial effects of priming on seed germination are related to the repair and build-up of nucleic acids, enhanced synthesis of RNA and proteins, repair of membranes, and enhanced respiratory activity of seeds (Elkoca et al., 2007). Moreover, the overall growth of plants is enhanced due to the seed-priming treatments (Jisha et al., 2013).

Similarly, we found that primed seeds demonstrate higher percentage of final germination (FG; \%) versus the control variant, higher germination speed (GS; seed day ${ }^{-1}$ ), higher mean daily germination (MDG; seed $\mathrm{day}^{-1}$ ), and shorter mean germination time (MGT; day). However, different from other authors who reports increased synchronization index (SI), i.e., the degree of homogeneity of germination over time due to seed priming (Damalas et al., 2019; Hussain et al., 2016b) we found a declined trend (increased SI values). Although do not have a full answer regarding this discrepancy of our findings with the reported results, we believe that it is related with different seed morphological characteristics of different species. In this respect we count the solid and less water permeable coat of pepper seeds than most of above mentioned species.

Although many reports indicated beneficial effect of hydro priming on seed germination and seedling growth in various crop plants such as chickpea, maize, wheat, canola, sunflower and rice (Lutts et al., 2016) in the current study hydro priming provided only slight improvements compared with the non primed seed, and only under optimum temperature conditions. Since the main disadvantage of hydropriming is uncontrolled water uptake by seeds this technique may result in unequal degree of seeds hydration and therefore lack of simultaneous metabolic activation. Hence, the definition of accurate imbibition duration, temperature, and water volume to ensure desired level of seed hydration to each specific plant species remains an open question.

We found that osmo priming by PEG 8000 provided best results in terms of germination parameters. It provided significantly higher germination parameters than control and hydro primed seeds, especially under suboptimum temperatures. Similarly, positive effects of PEG osmo priming were previously reported in wheat (Faijunnahar et al., 2017) and sorghum (Zhang et al., 2015). As it is explained, the higher and synchronized germination of primed seeds primarily occurs due to reduction in the lag time of imbibitions, enzyme activation, build-up of germination enhancing metabolites, metabolic repair during imbibition, and osmotic adjustment (Hussain et al., 2016b).

The priming effects are influenced by osmotic potential, temperature and time. Although usually water potential of priming agent varies from -1.0 down to $-2.0 \mathrm{MPa}$ (Girolamo \& Barbanti, 2012), values of water potential together with duration of the priming treatment should be always adjusted to species, cultivar, and sometimes seed lot (Lutts et al., 2016). By sharply increasing osmotic potential from -0.15 to $-0.5 \mathrm{MPa}$ we did not found differences 
regarding germination percentage (FG), or mean germination time (MGT). However, germination speed (GS) and mean daily germination (MDG) were significantly improved, especially under suboptimum temperature conditions. Similar to us, Kaur et al., (2002) in chickpea, Farooq et al., (2005) in tomato and Faijunnahar et al., (2017) in wheat have reported improved germination parameters by increasing PEG concentration up to $10 \%(\sim-0.5 \mathrm{MPa})$. A further increase might induce some adverse effects related with decreased water uptake in the osmo priming treatments, especially at water potential lower than -0.5 MPa of PEG (Elkoca et al., 2007).

There are contradicting reports regarding priming (imbibitions) period. While Farooq et al., (2005) have found that increasing priming duration in osmopriming treatments had a beneficial effect on wheat germination, other authors have found that increased priming duration drastically decreased the germination percentage and the other seed germination indices in soybean (Khalil et al., 2001) and chickpea (Elkoca et al., 2007). The authors conclude that over priming may cause oxygen deficiency and the build-up of inhibitors. We also analyzed two different priming periods; 48 and 72 hours of imbibitions, and found no effect on germination parameters of pepper seeds. Therefore, we conclude that there is no need to have priming periods longer than $48 \mathrm{hrs}$.

Following seed germination, chilling/sub optimum temperature stress hampers the shoot and root growth through reduced cell division and elongation, low respiration rate, and high oxidative stress (Hussain et al., 2016a). The results of our experiment confirmed that the rise of environment temperature to the optimum level was followed by a significant increase in seedlings dry matter; twenty day after sowing $\mathrm{DM}_{\text {plant }}$ at $24^{\circ} \mathrm{C}$ was $71 \%$ higher than at $18^{\circ} \mathrm{C}$. Similar effects of environment temperature on dry matter weight of the root system and the whole plant are reported in cauliflower (Kuçi et al., 2012), Arabidopsis (Zhu et al. 2015), and rice (Kiet and Nose, 2016). The difference in $\mathrm{DM}_{\text {plant }}$ was mostly a consequence of sharp increase in $\mathrm{DM}_{\text {shoot }}$. Therefore, under higher temperature conditions $\mathrm{DM}_{\text {root }}: \mathrm{DM}_{\text {shoot }}$ ratio was significantly reduced. Whereas, $\mathrm{DM}_{\text {root }}: \mathrm{DM}_{\text {shoot }}$ biomass partitioning is one of the mechanisms by which plants cope with limitations imposed by growth-constraining resources in the environment (Mašková and Herben, 2018), the decreased DM $_{\text {root }}$ :DM shoot $_{\text {ratio at higher }}$ environment temperature was attributed to decreased distribution of carbohydrates to root system and increased root respiration (Arai-Sanoh et al., 2010).

Although seedlings develop roots first, their relative investment into leaves versus roots as carbon and nutrient acquiring organs can change under different environment conditions. Our results confirmed that priming has significantly promoted growth and affected assimilate partitioning in the plant. Similar to us Kaur et al., (2002) have reported a 2-3 fold increase in the biomass of the roots and shoots of primed chickpea seedlings compared with the non-primed seedlings. In our experiment $\mathrm{DM}_{\text {root }}$ in primed seeds was $25-50 \%$ higher than control, which means that at the very start of their life, primed plants can more effectively and quickly use nutrients available in the soil (Mašková and Herben, 2018). However, the increase in $\mathrm{DM}_{\text {shoot }}$ of primed seeds versus control was even more notable (up to $80 \%$ ). The higher activities of amylase, invertase, sucrose synthase and sucrose phosphate synthase in shoots of primed seedlings in comparison to non-primed seedlings suggests a rapid hydrolysis 
of transitory starch formed in the shoots of primed seedlings leading to more availability of glucose for seedling growth (Kaur et al., 2002; Zhang et al., 2015). Furthermore, the higher invertase activity in shoots and roots of primed seedlings could help in phloem unloading thereby resulting in enhanced transport of sucrose from cotyledons to shoots (Kaur et al., 2002).

\section{Acknowledgments}

We are grateful to the contribution of MSc students Elona Fiku and Emanuel Dervishi for their contribution in experiment set up and data collection.

\section{References}

Arai-Sanoh, Y., Ishimaru, T., Ohsumi, A., \& Kondo, M. (2010). Effects of soil temperature on growth and root function in rice. Plant Prod. Sci. 13, 235-242. https://doi.org/10.1626/pps.13.235

Balliu, A., Sallaku, G., \& Nasto, T. (2016). The effects of some osmoprotectant compounds on growth parameters of pea plants ( Pisum sativum ) under saline conditions. Acta Hort. 1142, 377-382. https://doi.org/10.17660/ActaHortic.2016.1142.57

Damalas, C. A., Koutroubas, S. D., \& Fotiadis, S. (2019). Hydro-priming effects on seed germination and field performance of faba bean in spring sowing. Agric., 9. https://doi.org/10.3390/agriculture9090201

Elkoca, E., Haliloglu, K., Esitken, A., \& Ercisli, S. (2007). Hydro- and osmopriming improve chickpea germination. Acta Agric. Scand. Sect. B Soil Plant Sci., 57, 193-200. https://doi.org/10.1080/09064710600914087

Faijunnahar, M., Baque, A., Habib, M. A., \& Hossain, H. M. M. T. (2017). Polyethylene glycol (PEG) induced changes in germination, seedling growth and water relation behavior of wheat (Triticum aestivum L.) genotypes. Univers. J. Plant Sci., 5, 49-57. https://doi.org/10.13189/ujps.2017.050402

Farooq, M., Basra, S. M. A., Saleem, B. A., Nafees, M., \& Chishti, S. A. (2005). Enhancement of Tomato Seed Germination and Seedling Vigor By Osmopriming. Pak. J. Agri., 42, 3-4.

Finch-Savage, W. E., \& Bassel, G. W. (2016). Seed vigour and crop establishment: Extending performance beyond adaptation. J. Exp. Bot., 67, 567-591. https://doi.org/10.1093/jxb/erv490

Ghassemi-Golezani, K., Dalil, B., Moghaddam, M., \& Raey, Y. (2011). Field performance of differentially deteriorated seed lots of maize (Zea mays) under different irrigation treatments. Not. Bot. Horti Agrobot. Cluj-Napoca, 39, 160-163. https://doi.org/10.15835/nbha3926055

Girolamo, G., \& Di, Barbanti, L. (2012). Treatment conditions and biochemical processes influencing seed priming effectiveness. Italian Journal of Agronomy, 7, 178-188. https://doi.org/10.4081/ija.2012.25

Hamidi, R., \& Pirasteh-anosheh, H. (2013). Comparison effect of different seed priming 
methods on sunflower germination and seedling growth. Int. J. Agron. Plant Prod., 4, 1247-1250.

Hussain, S., Khan, F., Cao, W., Wu, L., \& Geng, M. (2016a). Seed Priming Alters the Production and Detoxification of Reactive Oxygen Intermediates in Rice Seedlings Grown under Sub-optimal Temperature and Nutrient Supply. Front. Plant Sci., 7, 1-13. https://doi.org/10.3389/fpls.2016.00439

Hussain, S., Khan, F., Hussain, H. A., \& Nie, L. (2016b). Physiological and biochemical mechanisms of seed priming-induced chilling tolerance in rice cultivars. Front. Plant Sci., 7, 1-14. https://doi.org/10.3389/fpls.2016.00116

Jisha, K. C., Vijayakumari, K., \& Puthur, J. T. (2013). Seed priming for abiotic stress tolerance: an overview. Acta Physiol Plant 35, 1381-1396. https://doi.org/10.1007/s11738-012-1186-5

Kaur, S., Gupta, A. K., \& Kaur, N. (2002). Effect of osmo- and hydropriming of chickpea seeds on seedling growth and carbohydrate metabolism under water deficit stress. Plant Growth Regul., 37, 17-22. https://doi.org/10.1023/A:1020310008830

Khalil, Sh. K. J. G. M., Mexal, J. G., \& Murray, L. W. (2001). Germination of soybean seed primed in aerated solution of polyethylene glycol (8000). J. Biol. Sci., 1, 105-107. https://doi.org/10.3923/jbs.2001.105.107

Kiet, H., \&Van, Nose, A. (2016). Effects of temperature on growth and photosynthesis in the seedling stage of the sheath blight-resistant rice genotype 32R. Plant Prod. Sci., 19, 246-256. https://doi.org/10.1080/1343943X.2015.1128108

Kuçi, H., Tafaj, I., Bici, B., Sallaku, G., \& Balliu, A. (2012). Effects of Cold Treatment on Morphological Characteristics and Growth Rate of Cauliflower (Brassica Oleracea Var.

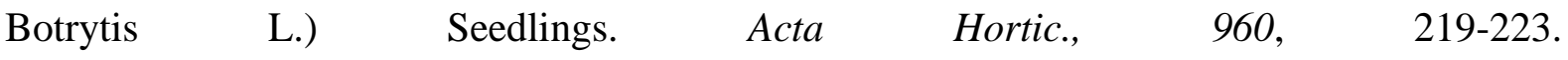
https://doi.org/10.17660/ActaHortic.2012.960.31

Lutts, S., Benincasa, P., Wojtyla, L., Kubala, S., Pace, R., Lechowska, K., Q. ... Garnczarska, M. (2016). Seed Priming: New Comprehensive Approaches for an Old Empirical Technique. New Challenges Seed Biol. - Basic Transl. Res. Driv. Seed Technol., 1-46. https://doi.org/10.5772/64420

Mašková, T., \& Herben, T. (2018). Root:shoot ratio in developing seedlings: How seedlings change their allocation in response to seed mass and ambient nutrient supply. Ecol. Evol., 8, 7143-7150. https://doi.org/10.1002/ece3.4238

Ranal, M. A., \& De Santana, D. G. (2006). How and why to measure the germination process? Rev. Bras. Bot., 29, 1-11. https://doi.org/10.1590/S0100-84042006000100002

Robertson, R. N., Highkin, H. R, Smydzuk, J., \& Went, F. W. (1961). The effect of environmental conditions on the development of pea seeds. Australian J. Biological Sci., 15(1) $1-15$. 


\section{Macrothink}

Salah, S.M., Yajing, G., Dongdong, C., Jie, L., Aamir, N., Qijuan, H., ... Jin, H. (2015). Seed priming with polyethylene glycol regulating the physiological and molecular mechanism in rice (Oryza sativa L.) under nano-ZnO stress. Sci. Rep., 5, 1-14. https://doi.org/10.1038/srep14278

Sharma, M., \& Laxmi, A. (2016). Jasmonates: Emerging Players in Controlling Temperature Stress Tolerance. Front. Plant Sci., 6. https://doi.org/10.3389/fpls.2015.01129

Villela, F. A., Doni Filho, L., \& Sequeira, E. L. (1991). Tabela de potencial osmótico em função da concentração de polietileno glicol 6.000 e da temperatura. Pesqui. Agropecuária Bras.

Waqas, M., Korres, N. E., Daud Khan, M., Nizami, A. S., Deeba, F., Ali, I., \& Haziq Hussain, H. (2019). Advances in the Concept and Methods of Seed Priming In Mirza Hasanuzzaman, M \& Fotopoulos, V (Eds). Priming and Pretreatment of Seeds and Seedlings (pp. 12-41). Springer Nature Singapore Pte Ltd.

Zhang, F., Yu, J., Johnston, C. R., Wang, Y., Zhu, K., Lu, F., ... Zou, J. (2015). Seed priming with polyethylene glycol induces physiological changes in sorghum (Sorghum bicolor L. moench) seedlings under suboptimal soil moisture environments. PLoS One, 10, 1-15. https://doi.org/10.1371/journal.pone.0140620

Zhu, J., Zhang, K. X., Wang, W. S., Gong, W., Liu, W. C., Chen, H. G., ... Lu, Y. T. (2015). Low temperature inhibits root growth by reducing auxin accumulation via ARR1/12. Plant Cell Physiol., 56, 727-736. https://doi.org/10.1093/pcp/pcu217

\section{Copyright Disclaimer}

Copyright for this article is retained by the author(s), with first publication rights granted to the journal.

This is an open-access article distributed under the terms and conditions of the Creative Commons Attribution license (http://creativecommons.org/licenses/by/4.0/). 